911.9:528

\author{
- етлін, . в нов \\ ьвівський н ціон льний університет імені в н \\ вул. . орошенк, 41, м. ввів, 79000, кр їн
}

озглянуто історію ст новлення т сьогодення к федри конструктивної геогр фії і к ртогр фії т н вч льної л бор торії геоінформ ційного моделюв ння і к ртогр фув ння. х р ктеризов но н прями н укової і н вч льно-виховної діяльності к федри.

лючові слов : к федр , л бор торія, конструктивн геогр фія, к ртогр фія, геоекологія, геоінформ тик .

федру створено 2000 р. вн слідок поділу к федри геоморфології н дві: геоморфології т конструктивної геогр фії і к ртогр фії. ьогодні н вч льною і н уковою роботою н к федрі з йм ються 13 викл д чів (дв професори, вісім доцентів і три систенти), т кож три співробітник н вч льно-допоміжного персон лу, одноч сно н вч ються п’ять-сім спір нтів. онед вн сумісник ми пр цюв ли відомі спеці лісти-екологи ьвівської міської р ди, ерж вного упр вління охорони н вколишнього природного середовищ у ьвівській обл сті, геологи й гідрогеологи “ еотехнічний інститут”, гідрологи ьвівського інституту “ іпроводгосп”. структурі к федри є н вч льн л бор торія геоінформ ційного моделюв ння і к ртогр фув ння, т кож к бінет геодезії і к ртогр фії т к бінет геогр фічної к рти [1].

сновником і першим з відув чем к федри ст в д-р геогр. н ук, проф. . ов льчук - відомий учений-геогр ф, геоморфолог, гідроеколог, з служений професор ьвівського н ціон льного університету імені в н $\mathrm{p}$ нк, к демік кр їнської екологічної к демії н ук, фунд тор львівської еколого-геоморфологічної школи. ід його проводом суттєво поповнено спеці ліст ми скл д к федри, відкрито нові спеці льності н к федрі т у риродничому коледжі. 2007-2008 pр. обов'язки з відув ч виконув в к нд. геол.-мін. н ук, доц. - олошин. липня 2008 р. $з$ відув чем ст в д-р геогр. н ук, проф. . е етлін [1,3].

ьогодні у скл ді к федри пр цює д-р біол. н ук, проф. . нтоняк, к ндид ти геогр фічних н ук, доценти . ург невич, . етровськ , . в нов, . ихнович, . илипович, . ричевськ i . кртчян, к ндид ти технічних н ук, доценти . озинський i . p вців, к нд. геогр. н ук, сист. . ойтків, сист. . ндрейчук, з відув ч л бор торії . люйник, інженери . обельк і . яльк, ст. л бор нт . ицько (див. вкл. 8).

езв ж ючи н нетрив лий період ст новлення к федри, її скл д суттєво змінився й омолодився. ільшість досвідчених викл д чів, які пр цюв ли від поч тку з снув ння к федри, сьогодні викл д ють в інших вищих н вч льних з кл д х кр їни. рофесор . ов льчук пр цює в иєві, у ціон льному університеті біоресурсів і природокористув ння кр їни, де з відує к федрою геодезії ік ртогр фії й очолює уково-дос-

(с) етлін ., в нов ., 2012 
лідний інститут землекористув ння т пр вового регулюв ння м йнових і земельних ресурсів. іншому столичному вищі - иївському н ціон льному університеті імені

p c евченк - пр цює . убіс, доцент к федри землезн вств т геоморфології й ст рший н уковий співробітник “ ндш фтної екології т ерокосмічного моніторингу н вколишнього середовищ ”. геологічний ф культет ьвівського н ціон льного університету перейшов доц. . олошин, який нині очолює к федру екологічної т інженерної геології і гідрогеології. ж ль, доц. . имоновськ переїх л н постійне місце прожив ння до й з лишил викл д цьку роботу [1].

уттєвий внесок у розвиток к федри зробили досвідчені спеці лісти в г лузі екології й гідрології, які з сумісництвом викл д ли н к федрі й сьогодні обійм ють пос ди в міській р ді, обл сному упр влінні охорони н вколишнього природного середовищ , іпроводгоспі. е доценти . ов льчук і . олодко, систенти . онд рчук, . елих і . орний.

укові дослідження к федри проводять у р мк х держбюджетних т госпдоговірних тем конструктивно-геогр фічної, геоекологічної й гідроекологічної тем тики, вони спрямов ні н пошук з кономірностей, вз ємозв'язків і мех нізмів розвитку різних, здебільшого небезпечних, природних і природно- нтропогенних процесів т явищ з використ нням системного, комплексного, структурного, дин мічного л ндш фтного, 6 сейнового, підходів, методів моніторингу, к ртогр фув ння і моделюв ння. ьогодні колектив к федри продовжує розпоч ті проф. . ов льчуком дослідження й зосередив ув гу н т ких головних н прям х $[1,3]$ :

$>$ конструктивно-геогр фічні (гідрологічні, гідробіологічні, гідрогеологічні, грунтові) дослідження н вколишнього природного середовищ ( . етлін, . нтоняк, - етровськ , . в нов, . ойтків);

$>$ геоекологія, л ндш фтн екологія, екологічн геоморфологія ( . етлін, . в нов, . ург невич, . етровськ , . ихнович, . обельк );

$>$ урбоекологія, техноекологія, нтропогенне л ндш фтозн вство, інженерн $m$ нтропогенн геоморфологія ( . етлін, . р вців, . в нов, . кртчян, . люйник, . обельк );

$>$ системно-структурний, історико-геогр фічний і геоекологічний н ліз б сейнових систем ( . ург невич, . ихнович, . илипович, . ндрейчук);

$>$ польові, ст ціон рні, експеримент льні і к ртогр фічні дослідження геосистем $m$ екзогенних процесів ( . етлін, . нтоняк, . в нов, . ихнович, . илипович, . кртчян, . ойтків);

$>$ моніторинг довкілля, екологічн експертиз , екологічний менеджммент, менеджмент природоохоронних територій ( . етлін, . ихнович, . етровськ , . ург невич, . ричевськ );

$>$ інженерно-екологічне обгрунтув ння проектів $m$ розробк шляхів покр щення cm нун вколищнього природного середовищ ( . ург невич, . в нов, . ихнович, . люйник);

$>\kappa$ ртогр фічні і топогр фо-геодезичні дослідження ( . озинський, . p вців, - обельк );

$>$ геоінформ ційне моделюв ння компонентів природного середовищ, дешифрув ння еро- й космознімків ( . в нов, . ихнович, . кртчян, . ндрейчук, . люйник); 
розробк проблем геогр фічного укр їнозн вств, термінології $m$ історї геогр фічних $і \kappa$ ртогр фічних досліджеень ( . етлін, . озинський, . р вців, . в нов);

історико-геогр фічний н ліз і синтез, історико-к ртогр фічне моделюв ння cm ну природно-господ рських систем ( . в нов, . ндрейчук).

г лом н укові інтереси к федри різном нітні. они охоплюють як проблеми методології і методики конструктивної геогр фії, т к і пит ння польових, ст ціон рних, експеримент льних і к ртогр фічних досліджень. х можн згрупув ти у дв головні н прями дослідницького пошуку: вл сне конструктивно-геогр фічний т к ртогр фічний.

півробітники к федри бр ли ктивну уч сть у держбюджетних тем х геогр фічного ф культету “ еогр фічні проблеми хідного регіону кр їни” (2002-2004), “ епресивні регіони кр їни” (2004-2006), “ ормув ння інформ ційного середовищ ст лого розвитку рп тського регіону кр їни (соці льно-демогр фічн, екологічн , рекре ційн , гробізнесов сфери)” (2007-2009), “ кологічн , демокультурн , соці льноекономічн т геополітичн безпек регіону: геогр фічні проблеми н м тері л х к рп тських обл стей кр їни" (2010-2012).

олектив к федри продовжує пр цюв ти н д тем ми, які виконують у меж х робочого ч су викл д чів: “ р нсформ ція природно-господ рських систем гірничопромислових територій” (2008-2010) і “ онструктивно-геогр фічні дослідження тр нсформ ційних процесів у територі льних систем х хідної кр їни” (2011-2013).

крім того, співробітники к федри виконув ли госпдоговірні теми “ н ліз існуючого ст ну системи спостережень 3 екологічною ситу цією н території ьвівської обл сті з метою з безпечення розробки концепції і прогр ми регіон льного моніторингу н вколишнього середовищ ” (2002), “ озробк т впров дження з ходів, спрямов них н збереження природно-історичного середовищ комплексної п м'ятки природи місцевого зн чення “ тільськ”, включно з основним їі компонентом - городищем - ст.” (2005). лени к федри ктивно виконув ли дослідження у р мк х укр їнсько-німецького проекту “ р нсформ ційні процеси у 6 сейні ерхнього ністр ”, який проводили під егідою (1997-2004), нідерл ндсько-польсько-білоруськоукр їнського проекту “ олин річки уг як екологічний коридор: ст н, з грози, охорон ” (1999-2001), т кож декількох інших міжн родних проектів 3 прогр мою TACIS.

езульт ти н укової роботи виявляються у з хист х к ндид тських дисерт цій конструктивно-геогр фічної тем тики, що присвячені вивченню геоекологічної ситу ції у 6 сейні хідного угу ( . ург невич, 2001), озточчі ( . етровськ , 2001), гірничопромислових територій ьвівської обл сті ( . в нов, 2001), б сейні ерхнього ністр ( . ихнович, 2004; . илипович, 2007), створенню земельних інформ ційних систем ( . кртчян, 2006), орг ніз ції гірських біосферних резерв тів ( . ричевськ , 2007), вивченню буроземів пр лісів кр їнських рп т ( . ойтків, 2008).

короткий ч с існув ння к федри вийшло близько 25 моногр фій, зокрем , Geomorfologia ekologiczna systemóv fluwialnych. Zagadnienia teoretyczne i metodyczne ( . ов льчук (спів вт.). рш в , 2000); Korytarz ekologiczny doliny Bugu: stan, zagrozenia, ochrona (. ов льчук (спів вт.). рш в , 2002); Roztocze. Srodowisko przyrodnicze ( . ов льчук (спів вт.). юблін, 2002); еоекологія озточчя (. ов льчук, . етровськ . ьвів, 2003); рофесор етро ись ( поряд. . ов льчук. ьвів, 2004); uнергетик л ндш фту ( . етлін. ьвів, 2005); онструктивне л ндш фтозн вство 
( . етлін. ьвів, 2006); онцепцї̈ суч сного л ндш фтозн вств ( . етлін. ьвів, 2006); ндш фти гірничопромислових територій ( . в нов. ьвів, 2007); тр тегія л ндш фту ( . етлін. ьвів, 2007); ром в орг нізмі людини і тв рин. іохімічні, імунологічні m екологічні спекти ( . ологуб, . нтоняк, . бич. ьвів, 2007); кологічні мех нізми орг ніз ції природних територі льних систем ( . етлін. ьвів, 2008); еок д строві дослідження гірничопромислових територій ( . в нов. ьвів, 2009); еоекологія ововолинського гірничопромислового р йону ( . в нов, . ов льчук, . ерещук. уцьк, 2009); етодологія $m$ методик експеримент льних л ндш фтозн вчих досліджень ( . етлін. ьвів, 2009); кологічний моніторинг регіону. кспертн оцінк ст нуіфункціонув ння ( ред. . ов льчук . ьвів, 2009), yроземи пр лісів кр їнських рn $m$ (. ойтків, . озняк. ьвів, 2009); еоекологічне моделюв ння $n$ м'яток природи $m$ iсторії ( ред. . ов льчук , . в нов . ьвів, 2010), истемн природнич геогр фія ( . етлін. ьвів, 2011) т ін. [3, 4].

ові розробки к федри ктивно впров джують у н вч льно-методичний процес н геогр фічному ф культеті. олективом к федри н пис но три підручники т близько 20 н вч льних і н вч льно-методичних посібників. окрем, опубліков но підручники кологічн геоморфологія ( . д менко, . ов льчук, . удько. в но- р нківськ, 2000); снови геоморфології ( . тецюк, . ов льчук. иїв, 2005) і кологія ( . ов льчук, . об к. ьвів, 2005). еред н вч льних посібників відзн чимо діоекологічні дослідження ( . в нов. ьвів, 2004); хорон вод ( . етровськ . ьвів, 2005); кологія людини ( . имоновськ . ьвів, 2006); кологічний менеджмент ( . етровськ . ьвів, 2006); одний к д стр ( . ург невич. ьвів, 2007); опогр фічний пр ктикум ( . озинський. ьвів, 2009); опогр фічне $і \kappa$ ртогр фічне креслення ( . озинський. ьвів, 2009); опогр фічн к pm (. озинський. ьвів, 2010); онструктивн геогр фія ( . етлін. ьвів, 2010); еоінформ ційне моделюв ння в конструктивній геогр фії ( . кртчян. ьвів, 2010); $m$ нд ртиз ція, метрологія $і$ сертифік иія довкілля ( . етровськ . ьвів, 2010); ідроекологічний моніторинг ( . ов льчук, . ург невич. ьвів, 2011); ді ційн екологія ( . в нов. ьвів, 2011) [3, 4].

півробітник ми к федри опубліков но брошури, довідники і словники: 8 H в льчук: біобібліогр ф. пок жмчик ( поряд. . омбровськ , . ихнович. ьвів, 2002); опогр фо-геодезичн термінологія ( . озинський. ьвів, 2002); опогр фо-геодезичний довідник ( . озинський. ьвів, 2005); опогр фо-геогр фічний словник ( . озинський. ьвів, 2007); риродні ресурси ьвівщини (. ов льчук, . в нов (спів вт). ьвів, 2009); ідроекологічний словник (. етровськ . ьвів, 2010); $i$ нер льні ресурси ьвівщини (. в нов (спів вт.). ьвів, 2010) т ін. [3].

федр бр л уч сть у створенні першої в кр їні тритомної “ кологічної енциклопедї̈”. т тті у цій енциклопедії пис ли . ов льчук, . етлін, . олошин, . в нов. сього близько 50 публік цій. рив є робот н уковців н д ст ттями до “нциклопедії суч сної кр їни” і “Encyclopedia. ввівський н ціон льний університет імені в н $\quad$ р нк".

олектив к федри підготув в пон д 40 методичних рекоменд цій з основних н вч льних предметів для студентів-екологів і геогр фів, із з безпечення н вч льних пр ктик, до н пис ння м гістерських і дипломних робіт тощо. один дцятирічну історію к федри випущено у світ пон д 500 н укових ст тей (близько $160-$ у ф хових вид ннях) і 140 тез доповідей н конференціях.

федр готує 6 к л врів, спеці лістів і м гістрів н денній і з очній форм х н вч ння н прямів підготовки “екологія $m$ охорон н вколишнього середовищ, ” “ “прик- 
л дн екологія $m$ зб л нсов не природокористув ння" т обслуговує н прями “геогр фія" і “туризмозн вство”, т кож проводить підготовку молодших спеці лістів у риродничому коледжі університету. стину м гістерських і дипломних робіт студенти виконують у р мк х н уково-дослідних тем.

гідно із н вч льними пл н ми з підготовки студентів-екологів к федр з безпечує викл д ння пон д 70 н вч льних дисциплін, зокрем : “ кологічн геогр фія”, “" ндш фтн екологія”, “ ідроекологія”, “ діоекологія”, “ кологія людини”, “ ехноекологія”, “ кологічн токсикологія”, “ кологічне інспектув ння”, “ кологічн етик”, “ кологічн політик ”, “ кологічний ризик”, “ р нспортн екологія”, “ одогоспод рськ екологія”, “ етодик екологічних досліджень”, “ оніторинг довкілля”, “ ніт рні норми і пр вил ”, “ кпертні системи в екологіі” т ін.

ісля з кінчення першого, другого і третього курсів студенти-екологи проходять чотиритижневі н вч льні пр ктики, н четвертому - виробничу і пед гогічну, н п’ятому - пед гогічну спеці лісти т систентську м гістри. икл д чі к федри т кож з безпечують проведення топогр фічної н вч льної пр ктики для студентів-геогр фів першого курсу.

ороку студенти беруть уч сть у сеукр їнських н укових конференціях “ е лії, проблеми т перспективи розвитку в кр їні” і “ хист н вколишнього середовищ . 6 л нсов не природокористув ння”, щор з ч стіше доповід ють н н укових з'їзд х, конгрес х, конференціях і семін р х. езульт ти н уково-дослідних робіт висвітлено у 6 г тьох публік ціях, зокрем, й у ф хових вид ннях. івень н укових пр ць визн ний й $з$ меж ми геогр фічного ф культету. прикл д, м гістр . люйник отрим в диплом 3 н йкр щу н укову доповідь н сеукр їнській студентській н уковій конференції ( ніпропетровськ, 2007), м гістр . оз к посів друге місце н сеукр їнському конкурсі студентських н укових робіт з геогр фії ( уцьк, 2009), студенти . улик і . рутень - друге ком ндне місце н сеукр їнській студентській олімпі ді з дисципліни “ кологія" ( иїв, 2009). оряд із н уковою діяльністю студенти беруть ктивну уч сть у різних екологічних кціях. окрем, у р мк х іжн родного молодіжного екологіч-ного форуму ( л вутич, 2006-2008) групи студентів щороку відвідують орнобильську [3].

ротягом нетрив лої історії зі стін к федри вийшло пон д 150 м гістрів і спецілістів. ипускники пр цюють у держ вних упр вліннях охорони н вколишнього природного середовищ т держ вних екологічних інспекціях обл сного і р йонного рівня, ьвівському обл сному виробничому упр влінні водного господ рств “ ьвівоблводгосп”, ьвівській геолого-розвідув льній експедиції, “еотехнічний інститут”, в екологічних відділ х підприємств т уст нов, різних гром дських орг ніз ціях і фонд х екологічного спрямув ння тощо. йліпші випускники з лиш ються пр цюв ти н к федрі і в риродничому коледжі університету, вступ ють до спір нтури чи прикріплюються до к федри здобув ч ми.

о інших форм н укової діяльності к федри н лежить уч сть їі співробітників в експертиз х проектів, орг ніз ції і проведенні міжн родних конференцій і польових семін рів, створенні тл сів, к рт і б нків д них, ред гув нні моногр фій і збірників н укових пр ць, опонув нні й рецензув нні дисерт цій, вторефер тів і ст тей.

федр виступ л орг ніз тором кр їнсько-польсько-російського семін ру “ розійно- кумулятивні процеси і річкові системи освоєних територій” ( ьвів- орохт , 2006), сеукр їнської н уково-пр ктичної конференції “ т н і перспективи розвитку конструктивної геогр фії” ( ьвів- орохт , 2010), круглого столу “ т н, проблеми і 
перспективи природничої геогр фії” ( ьвів, 2011). одноч с співробітники к федри були співорг ніз тор ми міжн родної конференції, присвяченої 120-річчю геогр фії у ьвівському університеті “ уч сні проблеми і тенденції розвитку геогр фічної н уки” ( ьвів, 2003), “ есурси природних вод рп тського регіону ( роблеми охорони т р ціон льного використ ння)” ( ьвів, 2007-2011), “ іомедичн електронік т фізичні методи в екології” ( ьвів- орохт , 2007-2008) т ін. [1].

езульт ти вл сних конструктивно-геогр фічних досліджень н уковців пробов ні н з'їзд х кр їнського геогр фічного тов риств, б г тьох міжн родних і всеукр їнських н уково-пр ктичних конференціях і семін р х. лени к федри бр ли ктивну уч сть у міжн родних конференціях з кордоном - у осії, ольщі, ілорусі, итві, імеччині, рокко, гипті, унісі і реції.

л годжено зовнішні зв'язки з ніверситетом імені рії юрі- клодовської т толицьким університетом у юбліні, рш вським т геллонським ( ольщ ), осковським, нкт- етербурзьким і з нським ( осійськ едер ція) університет ми, ентром досліджень грол ндш фтів і землекористув ння ( імеччин ), ільнюським університетом ( итв ). півпр цю у різні роки ре лізовув ли . ов льчук, . олошин, . убіс, . ихнович, . в нов, . илипович, · ндрейчук т інші у р мк х спільного німецько-укр їнського проекту “ р нсформ ційні процеси в б сейні ерхнього ністр ( хідн кр їн )”, виконув ного під егідою , польськоукр їнських дослідницьких проектів “ орфодин мічні процеси освоєних територій (н прикл ді лополіської, одільської і ередк рп тської височин т рп т)”, “ ивчення скл ду і вл стивостей лесів ольщі і хідної кр їни”, “ роблеми дослідження русел річок кр їнських рп т” т б г тьох інших. федр неоднор зово орг нізовув л обмінну н вч льну пр ктику студентів-екологів р зом із студент ми ніверситету імені юрі- клодовської у юбліні [1].

ри к федрі конструктивної геогр фії і к ртогр фії у 2001 р. створено н вч льну л бор торію геоінформ ційного моделюв ння і к ртогр фув ння. етою л бор торії $є$ н вч ння студентів-екологів зів використ ння -технологій, дист нційного зондув ння емлі, скл д ння екологічних к рт з допомогою комп'ютеризов них систем. різні ч си з відув ч ми л бор торії були . орженівський, . в нов, . ндрейчук, . імочко. ьогодні л бор торією з відує . люйник. л бор торії н явні чотири комп’ютери, великоформ тний ск нер, принтер, GPS-прийм ч, прил ди для екологічного контролю природного середовищ .

еред -прогр м, з якими пр цюють студенти, - продукти фірми ESRI: ArcInfo, ArcMap і ArcGIS різних версій. же декільк років у л бор торії використовують ліцензійну версію ArcGIS 9.0. оряд з цим відбув ється озн йомлення з т кими -продукт ми, як MapInfo, MicroStation, Surfer й Idrisi. ля дешифрув ння й опр цюв ння ерокосмічних д них з стосовують прогр мний комплекс ERDAS Imagine. н чну ув гу приділяють н вч нню ск нув ння к рт, їхнього зшив ння (PanaView), н пів втом тичного оцифровув ння тем тичних ш рів (EasyTrace), опр цюв ння к ртогр фічних творів 3 допомогою гр фічних ред кторів (CorelDraw, Photoshop), виведення н друк, оформлення мультимедійних презент цій (Microsoft Office PowerPoint) т ін. жливим елементом підготовки студентів є н вч ння пошуку необхідної к ртогр фічної, геогр фічної й геоекологічної інформ ції з допомогою мережі нтернет. оряд із роботою в н вч льній л бор торії з комп'ютерною технікою студенти вч ться проводити геоекологічні дослідження в польових умов х. н чн ув г приділен освоєнню студент ми методики рекогносцирув ння території, ï польового знім ння, прив'язув ння дос- 
ліджув них точок $з$ допомогою GPS-вимірюв ч , розроблення п спортів геоекологічних об'єктів, вимірюв ння різних геогр фічних т екологічних п р метрів н цих об'єКт х [2].

півробітники н вч льної л бор торії геоінформ ційного моделюв ння і к ртогр фув ння беруть ктивну уч сть у н вч льно-виховному процесі, з безпечують проведення пр ктичних робіт з курсів “нформ тик і систем тологія”, “ еоінформ тик”, “ еоінформ ційне моделюв ння”, “ ртогр фічне моделюв ння”, “ ідроекологічне моделюв ння”, “ ерокосмічні методи досліджень”, “ зи д них екологічної інформ ції”, “ еледетекція довкілля”. технічного сприяння пр цівників л бор торії ост нніми рок ми вид но шість моногр фій, дв н вч льні посібники й низку методичних рекоменд цій. л бор торії сприяють н пис нню курсових, дипломних і м гістерських робіт. ільшість екологічних к рт і моделей студентів к федри викон но в цій л бор торії [2].

ля з безпечення потреб н вч льно-виховного процесу й підвищення якості викл д ння основ геодезії, топогр фії й к ртогр фії при к федрі функціонує к бінет геодезії і к ртогр фії, пр цівники якого беруть ктивну уч сть у н вч нні студентів геогр фічного ф культету, з безпечують проведення пр ктичних робіт з курсів “ опогр фія з основ ми к ртогр фії”, “ ртогр фія і к ртогр фічне креслення”, “ ртогр фічні методи в екологіі”, “ уристичн к ртогр фія”, топогр фічного розділу комплексної н вч льної пр ктики студентів першого курсу геогр фічного ф культету, розробляють н вч льні посібники, методичні рекоменд ції і робочі зошити із з зн чених курсів, тир жують бл нки пр ктичних робіт і топогр фічні основи.

метою орг ніз ції н лежного збереження і використ ння к ртогр фічної інформ ції н геогр фічному ф культеті створено к бінет геогр фічної к рти (спецкімн ту).

к бінеті зберіг ються топогр фічні основи м сшт бу $1: 10$ 000, $1: 25$ 000, 1 : 50000 , 1 : 100000 і $1: 200000$ т ерознімки високої роздільної зд тності. ртогр фічн й ерокосмічн інформ ція зібр н для хідного регіону кр їни. півробітники к бінету н д ють допомогу в отрим нні спеці льного дозволу н використ ння к ртогр фічних м тері лів, їхнього пошуку, т кож стеж ть 3 дотрим нням вимог обліку й зберіг ння к ртогр фічної інформ ції, що ст новлять держ вну т ємницю [3].

1. в нов . федр конструктивної геогр фії і к ртогр фії : історія ст новлення й сьогодення / в нов, . ов льчук, . етлін // т н і перспективи розвитку конструктивної геогр фії : тер. сеукр. н ук.-пр кт. конф. - ьвів : ид вничий центр імені в н р нК , 2010. . 3-8.

2. в нов . езульт ти і н прями роботи н вч льної л бор торії геоінформ ційного моделюв ння і к ртогр фув ння / . в нов, . ндрейчук // т н і перспективи розвитку конструктивної геогр фії : тер. сеукр. н ук.-пр кт. конф. - ьвів : ид вничий центр імені в н к , 2010. - . .15-17.

3. федр конструктивної геогр фії і к ртогр фії / [упорядники : . . в нов, . . ов льчук, . . етлін]. - ьвів : ростір- , 2010. -56 с.

4. етлін . онструктивної геогр фії і к ртогр фії к федр / . етлін // Encyclopedia. ьвівський н ціон льний університет імені в н р нк : в 2 т. . . . - ьвів : імені в н р нк , 2011. - .643-644. 


\title{
DEPARTMENT OF CONSTRUCTIVE GEOGRAPHY AND CARTOGRAPHY
}

\author{
V. Petlin, E. Ivanov
}

Ivan Franko National University of Lviv, . Doroshenko St., 41, UA - 79000 Lviv, Ukraine

The history and present state of the department of constructive geography and cartography and educational laboratory of GIS mo-delling and cartography are considered. Directions of scientific and educational activities of the department are described.

Key words: department, laboratory, constructive geography, cartography, geoecology, geoinformation.

$$
\text { • етлин, - в нов }
$$

ввовский н иион льный университет имени в н

$$
\text { ул. . орошенко, 41, г. ьвов, 79000, кр ин }
$$

ссмотрено историю и современное положение к федры конструктивной геогр фии и к $\mathrm{p}$ тогр фии и учебной л бор тории геоинформ ционного моделиров ния и к ртогр фиров ния.

$\mathrm{x}$ р ктеризов но н пр вления н учной и учебно-воспит тельной деятельности к федры.

лючевые слов : к федр , л бор тория, конструктивн я геогр фия, к ртогр фия, геоэкология, геоинформ тик . 